\title{
Aspectos da Formação Econômica de Mato Grosso do Sul *
}

\author{
Fabricio José Missio ${ }^{1}$ \\ Rozimare Marina Rodrigues Rivas ${ }^{2}$
}

\section{Resumo}

O objetivo deste artigo é analisar aspectos da formação econômica de Mato Grosso do Sul (MS). Em termos teóricos, admite-se que o desenvolvimento do estado de MS é historicamente dependente dos ciclos externos (nacionais e internacionais) e que, por isso, a sua trajetória de desenvolvimento tem traços marcantes de uma inserção periférica. Portanto, propõem-se uma análise integrada que leva em consideração uma orientação teórica mais geral, vinculada ao pensamento de grandes intérpretes brasileiros como Caio Prado Jr. e Celso Furtado e, também, uma análise que leva em consideração o protagonismo e as especificidades locais. As conclusões apontam que, voluntária ou involuntariamente, a incorporação do Estado ocorreu em termos periféricos, sendo a ele incumbido o papel de ser um dos "celeiros" do Brasil.

\section{Palavras-Chave}

Formação econômica. Especificidades locais. Desenvolvimento regional.

\begin{abstract}
The objective of this article is to analyze the economic formation of Mato Grosso do Sul (MS). It is assumed that the MS development is historically dependent on external cycles (national and international) and hence its development trajectory has striking features of a peripheral insertion. Therefore, we propose an integrated analysis that takes into account a more general theoretical perspective, linked to the thinking of Caio Prado Jr. and Celso Furtado. Besides it is made an analysis that takes into account the role and the specific local conditions. The findings present that the incorporation of the State in the process of capitalist accumulation occurred in peripheral terms, and it was entrusted in it the role to develop its agricultural vocation.
\end{abstract}

\section{Keywords}

Economic formation. Specific local conditions. Regional development.

\section{JEL Classification}

N96, O20.

- Os autores agradecem os comentários recebidos de Paulo Roberto Cimó Queiroz (UFGD), Fernanda Cimini Salles (UFMG), Adayr da Silva Ilha (UFSM) e dos pareceristas. Fabricio Missio agradece o suporte do CNPq e da Capes. As exonerações de responsabilidade usuais se aplicam.

1 Professor - Universidade Federal de Minas Gerais (UFMG) - Endereço: Av. Antônio Carlos, 6627. CEP: 31270-901 - Belo Horizonte/MG - Brasil - E-mail: fabriciomissio@gmail.com ORCiD: https://orcid.org/0000-0003-4561-6039

2 Mestre em Desenvolvimento Regional e Sistemas Produtivos - Universidade Federal da Grande Dourados - Endereço: Rua João Rosa Góes, 1.761 - CEP: 79.825-070 - Vila Progresso - Dourados/MS Brasil - E-mail: rmrr.pp@gmail.com - ORCiD: https://orcid.org/0000-0002-9090-207X Recebido: 24/01/2018. Aceite: 23/07/2018.

(c) (i) (\$) Esta obra está licenciada com uma Licença Creative Commons Atribuição-Não Comercial 4.0 Internacional. 


\section{Introdução}

O objetivo deste artigo é propor uma análise capaz de elucidar a formação econômica do estado de Mato Grosso do Sul (MS). A hipótese assumida é a de que o desenvolvimento de MS é historicamente dependente dos ciclos externos (nacionais e internacionais) e que, portanto, a sua trajetória de desenvolvimento tem traços marcantes de uma inserção periférica, tanto do ponto de vista internacional como do processo de desenvolvimento nacional. Para tanto, parte-se da premissa de que as decisões que afetam a produção de uma determinada economia/região são tomadas em função da dinâmica e dos interesses de grupos das economias/regiões desenvolvidas ${ }^{1}$ associadas aos interesses internos/locais.

A justificativa para a análise baseia-se no entendimento de que, após completar 40 anos desde a sua criação (Lei Complementar $n^{\circ} 31,11$ de outubro de 1977), o MS carece de análises capazes de elucidar os aspectos da sua formação histórica e econômica. Portanto, o presente estudo procura estabelecer e enriquecer as conexões teóricas existentes, ao mesmo tempo em que avança na compreensão do objeto de estudo ao propor novas interpretações ou mesmo lançar, eventualmente, uma luz nova sobre as interpretações já consolidadas.

Em termos metodológicos, o estudo situa-se entre os trabalhos nos quais o investigador analisa uma série de casos com o objetivo de mostrar que muitos deles podem ser iluminados de maneira útil mediante um conjunto de conceitos e categorias ou por um modelo concreto (Skocpol, Somers 1980). Nesse caso, o "sentido da colonização" e o "modelo centro-periferia" são as referências do nosso modelo analítico. Além disso, o estudo também incorpora aspectos da metodologia da análise regional comparada. Nesse caso, o trabalho está alinhado com as observações de Targa (1991, 1-2), quais sejam: (i) dentro de um país, uma região só pode existir, e, portanto, ser tratada como tal, se ela se particularizar em um elenco de questões, tais como: sua economia, sua sociedade, sua cultura, sua formação histórica (admitimos que o MS tem particularidades específicas que o diferenciam); (ii) a análise de uma região tratada no seu isolamento e no seu "absoluto" carece de sentido; uma análise de desenvolvimento regional só consegue explicitar as peculiaridades desse desenvolvimento desde um ponto de vista comparativo; essa comparação deve ser realizada com, pelo menos,

1 Tal enfoque implica reconhecer que, no plano político e social, existe algum tipo de dependência, que teve início historicamente com a expansão das economias dos países capitalistas originários. 
uma região do país (a análise da formação econômica de MS tem como referência suas particularidades em relação a formação da região sudeste, especialmente de São Paulo); (iii) ao diferenciarem-se, as regiões de um país hierarquizam-se desde pontos de vista diversos, tais como o político e o econômico, separando-se em "centrais" e "periféricas"; (iv) se uma região "central" ou uma "periférica", depende da natureza dos temas que serão investigados; e, (v) a comparação entre uma região e o todo "nacional" carece de precisão, embora seja um passo analítico de extrema importância.

Por fim, cumpre ressaltar que os autores reconhecem que, diante da presença de intelectuais em estudos de fôlego sobre a dinâmica regional brasileira, elaborada a partir de universidades paulistas, as interpretações aplicadas aos estudos das mais diversas regiões brasileiras incorporaram, em boa medida, a mesma análise pensada para São Paulo, aplicando-a uniformemente para o resto do Brasil. Além disso, a presença dos estudos cepalinos (de extrema relevância e importância para entendermos o Brasil e a América Latina), da teoria da dependência e das ricas abordagens elaboradas pelos estudos do IE/UNICAMP, sobrepuseram-se aos estudos regionais - escritos nas próprias regiões -, ofuscando as dinâmicas internas das mais diversas regiões do país. A própria história demonstrou que o fato de uma economia regional não estar integrada à economia paulista não significa que estava fadada ao atraso, como é o caso de Santa Catarina, Rio Grande do Sul e Minas Gerais, por exemplo.

Entende-se, assim, a necessidade de se considerar o potencial endógeno de cada região no sentido de que elas também têm condições de impulsionar o crescimento local. Nem tudo depende do "centro", como nem tudo depende da própria "periferia", ambas se complementam. A "periferia" também tem uma dinâmica que se articula e impulsiona ritmos de acumulação. Esta dinâmica emerge a partir de um esforço interno, seja das elites locais ou do próprio movimento de acumulação.

Nesse contexto, é possível identificar certas fases de acumulação de capital em Mato Grosso do Sul como, por exemplo, nas charqueadas, especialmente entre as décadas de 1930 e 1960; ou no ramo da erva-mate- para além da Companhia Mate Laranjeira- formando um complexo ervateiro com a presença de inúmeras atividades econômicas que tinham certo grau de autonomia em relação à força econômica de São Paulo. 
Ou seja, embora a hipótese deste trabalho seja a de que a trajetória de desenvolvimento de MS tenha traços marcantes de uma inserção periférica, isso não significa que ela é pensada em termos uniformes. Pelo contrário, ao admitir o protagonismo e as especificidades locais reforçamos a ideia de uma dinâmica própria que articula e impulsiona ritmos de acumulação, ainda que esta seja insuficiente para determinar um desenvolvimento autônomo da região. Portanto, argumentamos que nossa análise deve ser vista como complementar e não divergente da análise dos principais autores da historiografia da região (como Queiroz, Borges, Abreu e Bittar, entre outros).

O trabalho encontra-se dividido em três seções, além desta introdução e das considerações finais. $\mathrm{Na}$ seção 2, apresenta-se o marco teórico a ser desenvolvido, em que se discute o desenvolvimento de MS a partir das concepções de Caio Prado Jr. (sentido da colonização) e Celso Furtado (modelo centro-periferia). A seção seguinte destaca a influência das especificidades locais na inserção periférica do Estado. A quarta seção evidencia aspectos históricos essenciais do desenvolvimento sul-mato-grossense.

\section{O "Sentido da Colonização" em Mato Grosso/Mato Grosso do Sul}

Conforme apontado por Caio Prado Júnior (2011), a formação e a evolução de um povo se dá por meio de um "sentido" e, ao estudar a sua história, é imprescindível que se tenha este reconhecimento, pois nele está boa parte das respostas aos acontecimentos que ocorrem numa determinada nação/região. Sendo assim, a formação política e econômica do Brasil tem suas origens em grande parte no e em decorrência de seu processo de colonização.

Segundo Prado Jr. (2011, 11), "O passado, aquele passado colonial que referi acima, aí ainda está, e bem saliente; em parte modificado, é certo, mas presente em traços que não se deixam iludir". Ou seja, se é verdade que o Brasil contemporâneo do século XXI é um país com profundas transformações em relação ao seu passado colonial, também é verdade que continuam presentes realidades já muito antigas. 
Se, de maneira geral, a formação nacional é marcada pelo processo de colonização, assim também o é, em caráter particular, a influência desse processo na formação histórica, política e econômica de Mato Grosso do Sul. Nesse contexto, o entendimento desses elementos é fundamental na compreensão da evolução (estagnação) de determinadas regiões brasileiras ${ }^{2}$ frente ao avanço do processo de acumulação capitalista global.

Como destacado por Caio Prado Júnior (2011), o processo de colonização não tinha outra finalidade que não a de exploração dessas terras, uma vez que os colonizadores buscavam artigos, especialmente metais preciosos e especiarias, capazes de serem comercializados com a Europa. Isto é, não havia a intenção de povoar este território. Nas palavras do autor, "É o comércio que os interessa, e daí o relativo desprezo por este território primitivo e vazio que é a América; e, inversamente, o prestígio do Oriente, onde não faltava objeto para atividades mercantis" $(2011,16)$.

No Brasil, a demora em descobrir as jazidas de metais preciosos pelos portugueses obriga-os a povoar o país com o objetivo de "abastecer e manter as feitorias que se fundassem e organizar a produção dos gêneros que interessassem ao seu comércio". (Prado Jr. 2011, 17). Ou seja, já no início do processo de colonização, há elementos que permitem supor que a incorporação do Brasil ao processo de Divisão Internacional do Trabalho (DIT) seguiu uma lógica que condicionou a sua inserção ao papel de fornecer produtos primários (sejam agrícolas ou minerais) à Economia Internacional.

Essa lógica pode ser vinculada também ao processo de formação de Mato Grosso do Sul (MS). Sendo assim, o "sentido da colonização" de Caio Prado Júnior (2011), ${ }^{3}$ além do ponto de partida, será uma espécie de guia (fio condutor) que conecta a análise efetuada. ${ }^{4}$ A lógica do "sentido da

2 O objetivo deste artigo não é estudar a Região Centro-Oeste e, sim, o processo de formação dos estados de Mato Grosso e, principalmente, Mato Grosso do Sul. Todavia, em alguns momentos será necessário retomar a região como um todo, tendo em vista a existência de características (históricas, políticas e econômicas) que são comuns a todos os estados que a compõe. Ou ainda, ciente das especificidades, destaca-se a existência de tendências gerais, como foi o processo de colonização e as políticas consubstanciadas na "marcha para o oeste" etc.

3 Caio Prado Júnior é considerado um dos mais importantes intérpretes do Brasil (Candido 1967). Conforme aponta Faria $(2008,3)$ : "Hoje sujeitas a críticas que as tornam mais ricas e complexas, as ideias de Caio Prado Júnior continuam uma referência fundamental para quem quer compreender as causas de nosso atraso socioeconômico. Seja para concordar ou criticar, ele é o ponto de partida para as análises atuais [...]". Nesse sentido, apesar do reconhecimento de que existe um amplo debate em torno de suas ideias, este trabalho adota como fundamentação teórica as concepções do autor. Para abordagens alternativas a essa concepção ver, entre outros, Fragoso (1992) e Fragoso e Florentino (1993).

4 Esse tipo de análise não é necessariamente original. É possível encontrar análises que seguem o mesmo caminho, especialmente aquelas dedicadas a estudar a região nordeste do Brasil. 
colonização" em Mato Grosso uno (MT uno) (atuais estados de Mato Grosso e Mato Grosso do Sul) pode ser identificada em três períodos: i) o primeiro refere-se ao período colonial, em que a região atendeu à lógica determinada por Portugal (de exploração de metais preciosos, principalmente; mas também como fornecedora de mão de obra indígena para a produção realizada em outras regiões do país); ii) o segundo ocorre a partir da reorganização do processo produtivo brasileiro (industrialização), em que o antigo sul de Mato Grosso (SMT) (atual Mato Grosso do Sul) é incorporado ao mercado nacional como produtor de bens alimentícios necessários ao abastecimento das classes trabalhadoras urbanas emergentes; e, iii) o período atual, que, apesar da sua maior complexidade, indica que a região seja produtora de commodities a fim de atender à demanda externa, especialmente do mercado chinês.

\subsection{Período sob a Orientação "Colonial"}

Com relação a esse primeiro momento, convém inicialmente destacar que o litoral foi o ponto de partida da colonização brasileira, onde se desenvolveram as primeiras atividades econômicas, isto é, as atividades produtivas direcionadas à exploração das características daquela localidade que permitissem a produção de bens de interesse da metrópole (Portugal), como a cana-de-açúcar. De acordo com Holanda (1995), as terras do Nordeste brasileiro eram de boa qualidade e aptas para o desenvolvimento altamente lucrativo da lavoura da cana-de-açúcar. Entretanto, havia a necessidade de mão de obra para realização do trabalho, uma vez que "o que o português vinha buscar era, sem dúvida, a riqueza, mas riqueza que custa ousadia, não riqueza que custa trabalho" (Holanda 1995, 49). Como as primeiras tentativas de escravização do índio não obtiveram o êxito esperado (dada a resistência indígena), os colonos portugueses recorreram à mão de obra escrava vinda da África (onde Portugal também mantinha colônias). ${ }^{5}$

Guimarães Neto (1997) argumenta, por exemplo, que "o que constituiu o Nordeste (e o próprio Brasil) em fases posteriores, surgiu e se desenvolveu inicialmente como parte do movimento mais geral de expansão do capitalismo mercantil, na aurora mesmo do capitalismo e da economia-mundo centrada na Europa, com funções muito precisas de uma colônia e no quadro mais geral da divisão de trabalho que começava a se consolidar" (p. 41).

5 Holanda $(1995,48)$ afirma que, na formação dos latifúndios coloniais, os negros sempre estiveram presentes, como se fossem fatores obrigatórios. 
Para além da já bem conhecida lavoura açucareira no Brasil (Furtado 2005), cumpre ressaltar, para os propósitos deste trabalho, que a lucratividade da lavoura de cana-de-açúcar não era homogênea no espaço brasileiro. Em algumas regiões, ao contrário do que ocorreu no litoral nordestino, a produtividade/lucratividade da lavoura era reduzida, como foi o caso do planalto paulista. Diante dessa situação, muitos produtores desse local recorreram a outras atividades, como a lavoura de trigo, por exemplo. Mas o ponto é que, enquanto os rendimentos obtidos com o cultivo da cana-de-açúcar justificavam a adoção da mão de obra africana em boa parte dos empreendimentos, para os produtores dessa região, esse custo era alto (frente à baixa produtividade da lavoura). Assim, uma das alternativas encontradas para contornar a situação foi adentrar "os sertões" da América Portuguesa em busca de índios a fim de torná-los fonte de mão de obra escrava. Surgem, nesse contexto, as primeiras penetrações no território sul-mato-grossense pelos denominados bandeirantes da capitania de São Vicente.

Entre o final do século XVI e início do século XVII, o atual estado de Mato Grosso do Sul fazia parte dos domínios espanhóis (de acordo com o Tratado de Tordesilhas) ${ }^{6}$, os quais estabeleceram nesse território um núcleo denominado Santiago de Xerez (que perdurou até 1632). A região contou ainda com a presença de jesuítas com vínculos espanhóis na denominada "missões do Itatim" (Queiroz 2008, 16). Foi somente a partir do século XVII que este território ingressou na história da América Portuguesa, decorrente de ações dos denominados bandeirantes da capitania de São Vicente, que adentraram o lugar com o objetivo de aprisionar e escravizar os índios (Queiroz 2008). Em outras palavras, a presença do bandeirante tem um caráter "despovoador", dado que, nesta busca por escravos índios, eles "aprisionaram, dizimaram ou afugentaram os grupos inicialmente ali estabelecidos, como os Guarani” (Queiroz 2008, 17).

Isto posto, observa-se que, no princípio, a ocupação do espaço mato-grossense não ocorreu a partir de uma preocupação efetiva de dominação de território, pois tratava-se de uma "incorporação" muito mais ligada aos circuitos econômicos, ou seja, cumpria a lógica de fornecimento de índios escravos que seguiam rumo ao planalto paulista para tornar-se mão de obra

${ }_{6}$ O Tratado de Tordesilhas foi assinado com o intuito de resolver os problemas relacionados aos domínios territoriais descobertos e/ou a serem descobertos por Portugal e Espanha. O Tratado foi assinado em 1494 e definia que terras situadas até 370 léguas a leste de Cabo Verde seriam pertencentes a Portugal e terras a oeste dessa linha pertenceriam à Espanha. 
nas lavouras de trigo (Queiroz 2009, 3). Ou ainda, este território nada mais era do que uma distante periferia (Queiroz 2011).

Contudo, a situação relativa à ocupação foi alterada assim que as jazidas de ouro de aluvião foram descobertas, casualmente, pelos bandeirantes por volta de 1718/1719 em Cuiabá (nas margens do Coxipó). A partir de então, ocorreu de fato uma ocupação do território de Mato Grosso pelos luso-brasileiros, bem como a coroa portuguesa passou a demonstrar interesse pela posse da terra.

Destaca-se que a descoberta do ouro limitou-se à área em que se encontra o atual Mato Grosso e, portanto, ao antigo sul de Mato Grosso atribuía-se o papel de "área de passagem" entre Cuiabá e São Paulo. Esse trajeto logo deu início às chamadas monções, uma forma alternativa de deslocamento por meio da qual desenvolveram-se expedições fluviais que permitiram uma corrente regular de comunicação e comércio (Queiroz 2008). É nesta fase de exploração aurífera que Cuiabá tornou-se o centro político decisório de Mato Grosso uno (Bittar 2009). A sede da recém-criada Capitania de Mato Grosso (1748), denominada Vila Bela da Santíssima Trindade, foi estabelecida neste local.

Verifica-se, assim, que, a princípio, o antigo Mato Grosso não despertava interesse algum da coroa portuguesa, pelo fato de que, naquele primeiro instante, não apresentava um produto tropical que gerasse excedente econômico, tal como a produção da cana-de-açúcar que se desenvolvia entre outras regiões. Mesmo com a descoberta do ouro, não houve o desenvolvimento de uma diversificação produtiva, tanto é que, após o declínio do período aurífero, a região "sobreviveu" a partir do estabelecimento de uma pequena produção mercantil.

A expansão da colonização portuguesa para o antigo Mato Grosso passou a ter maior apelo político do que econômico, sendo que, para garantir seu domínio sobre a exploração das zonas auríferas, fazia-se necessário manter a posse do antigo sul de Mato Grosso, terras estas que pertenciam aos espanhóis de acordo com o Tratado de Tordesilhas.

O período da mineração propiciou a expansão territorial rumo ao interior. Segundo Furtado $(2005,81)$ : "A base geográfica da economia mineira estava situada numa vasta região compreendida entre a serra da Mantiqueira, no atual Estado de Minas, e a região de Cuiabá, no Mato Grosso, passan- 
do por Goiás". De acordo ainda com Prado Jr. (2011, 29), tanto as ações bandeirantes e mais tarde a exploração das minas foram responsáveis pelo processo de interiorização brasileiro, tornando, assim, possível a fixação de "núcleos estáveis e definitivos" em Minas Gerais, Mato Grosso e Goiás.

Contudo, a prioridade não era criar condições que propiciassem o desenvolvimento do antigo território mato-grossense (aliás, isso vale para todo o território nacional), mas sim proporcionar lucro à Coroa Portuguesa. Segundo Fausto (2006 apud Queiroz 2007, 52-53):

Os metais preciosos realizaram um circuito triangular: uma parte ficou no Brasil, dando origem à relativa riqueza da região das minas; outra seguiu para Portugal, onde foi consumida no longo reinado de Dom João V (1706-1750), em especial nos gastos da Corte e em obras como o gigantesco palácio-convento de Mafra; outra parte, finalmente, de forma direta, via contrabando, ou indireta, foi parar em mãos britânicas, acelerando a acumulação de capitais na Inglaterra.

O auge da mineração no Centro-Oeste brasileiro deu-se no século XVIII, e sua exploração durou até o final do mesmo período. Já no início do século XIX (por volta da década de 1830), começou de fato o primeiro movimento de ocupação efetiva por população não indígena do território hoje pertencente a Mato Grosso do Sul. Eram as migrações oriundas de áreas mais povoadas como Minas Gerais, São Paulo e, também, do entorno de Cuiabá, desenvolvendo um processo de ocupação voltado especialmente à pecuária bovina. Conforme Bittar $(2009,50):$ "...] enquanto o ouro fez Cuiabá, as pegadas do boi configuraram o sul". Tal movimento se enquadra no que José de Souza Martins $(1996,27)$ chamou de "Frente de Expansão", sendo o período marcado pelos constantes embates entre esses pioneiros e os povos indígenas que ali habitavam e que foram sendo expropriados de suas terras.

A pecuária tornou-se a atividade econômica predominante no antigo sul de Mato Grosso. Uma implicação importante que deriva desse período é a formação dos latifúndios pecuaristas, que dão origem à elite econômica que ao longo do tempo transcendeu também, direta ou indiretamente, ao 
cenário político. Segundo Esselin $(2011,12)$ : "O Estado confunde-se com o gado. A maioria de seus mais destacados representantes no meio político tem estreita ligação com ele. São, geralmente, latifundiários e pecuaristas que exercem o poder e nele se revezam a cada eleição”.

Enquanto que para Esselin (2011) o gado já estava presente no SMT desde o século XVI, quando os espanhóis fundaram a cidade Santiago de Xerez, para Borges (2001) a exploração da pecuária, no antigo Mato Grosso, iniciou-se no ano de 1737. Não obstante, foi somente ao final do século XIX que as fazendas começaram a se destacar e a pecuária ganhou importância econômica. No começo do século XX, a pecuária foi se tornando cada vez mais uma atividade intensa e permanente na região mato-grossense, processo que recebeu contribuição significativa com a construção da estrada de Ferro Noroeste do Brasil (Borges 2001).

Ao analisar a afirmação da autora Marisa Bittar (2009, 47): "além dos irmãos Lopes, vieram ainda os Barbosa, os Souza e os Garcia", verifica-se que estes e alguns outros sobrenomes tiveram, direta ou indiretamente, alguma participação na formação do estado tanto em âmbito econômico quanto político. A autora afirma, ainda, que a Guerra do Paraguai ocasionou a dispersão, a perda de terras e até mesmo a morte de muitas dessas famílias. Assim, se por um lado a Guerra da Tríplice Aliança levou a uma redução da população como um todo no antigo sul de Mato Grosso, por outro lado, Bittar (2009) revela que com o fim do conflito houve um surto populacional, uma vez que se tornou explícita a necessidade de maior integração e ocupação desse território fronteiriço. Acrescenta-se, ainda, que a demarcação dessas fronteiras impulsionou o desenvolvimento de outra atividade econômica no antigo sul de Mato Grosso, ou seja, a extração da erva-mate.

A pecuária e a extração da erva-mate foram, portanto, as principais atividades desenvolvidas ao final do século XIX e início do século XX no SMT, sendo que a primeira desenvolveu-se num modelo extensivo e com baixo nível técnico, enquanto que a segunda ocorreu mediante a exploração de suas plantas nativas, ambas de forma predatória. Contudo, a relação com os mercados atendidos tinha lógicas diferentes, uma vez que enquanto a exploração da erva-mate estava inserida no comércio internacional, a pecuária esteve voltada ao mercado nacional. Para Queiroz (2008, 22): 
[...] o processo de ocupação aqui referido, centrado na pecuária bovina, pôde representar para o SMT o início de uma efetiva inserção nos circuitos econômicos nacionais, graças à atração exercida pelo mercado do sudeste (sobretudo, inicialmente, o mercado representado pela cidade do Rio de Janeiro).

Ambas as atividades caracterizavam-se pelo baixo valor agregado dos produtos comercializados. No caso da pecuária, especialmente no antigo sul de Mato Grosso, eram criados os gados magros e estes eram engordados nas invernadas mineiras e daí partiam aos centros consumidores, localizados principalmente no Rio de Janeiro. Já no caso da erva-mate, o problema estava no fato de que a erva exportada para a Argentina era do tipo cancheada (não processada). Ou seja, posteriormente ela era beneficiada e vendida pelo país vizinho com maior valor agregado.

Neste período, outros dois produtos fizeram parte da história do antigo Mato Grosso, ambos também voltados à exportação e de origem extrativista, ou seja, a ipecacuanha (poaia) e a borracha. ${ }^{7}$ A primeira começou a ser explorada logo após a mineração entrar em declínio e não despertou um interesse maior nos exploradores, devido à instabilidade de seu preço em nível internacional.

Já a borracha apresentou participação significativa entre 1907 e 1916 nas exportações de Mato Grosso. A média de participação percentual nas exportações, considerando os valores monetários totais, foi de aproximadamente de $60 \%$. Contudo, as dificuldades enfrentadas acabaram por prejudicar o ciclo de expansão dessa atividade, entre as quais se destacam aquelas relacionadas à ausência de vias de comunicação, à atuação de intermediários no processo de vendas e, principalmente, ao surgimento deste produto no Oriente com menor valor comercial em relação ao praticado por Mato Grosso a partir de 1910 (Borges 2001).

Por fim, cumpre ressaltar nesse período (especialmente durante o Império) a interpretação de alguns autores quanto ao papel que o Estado (tanto o governo provincial quanto o governo imperial) teve enquanto elemento impulsionador da demanda regional, seja como principal empregador e/ou como (muitas vezes) o principal cliente de produtos locais, tanto para o exército

7 Estes dois produtos estavam localizados no território que hoje abrange o atual Mato Grosso. 
quanto para a administração estatal. Conforme destaca Garcia (2001), a melhora no sistema de arrecadação, principalmente a partir de 1850 , em conjunto com os investimentos do governo imperial nas suas instalações militares e na fixação de novas unidades militares pode ter contribuído para dinamizar a economia da província. ${ }^{8}$

\subsection{A Reorganização do Processo Produtivo Brasileiro}

O segundo momento em que identifica-se o "sentido da colonização" de Mato Grosso do Sul engloba o movimento nacionalista capitaneado por Getúlio Vargas, o qual criou o programa denominado "Marcha para o Oeste”, que seria, de acordo com Abreu (2003, 272): “[...] o primeiro grande movimento de 'integração planejada' em terras mato-grossenses, assumindo posição de política migratória para brasileiros [...]”. Ou ainda, segundo Naglis (2013), a Marcha para o Oeste tinha como objetivo a expansão agrícola e a colonização.

Durante esse período, é reconhecidamente notória a preocupação com o povoamento das fronteiras nacionais. Porém, como aponta Abreu (2003, 274), neste projeto foi desconsiderada a "legitimidade da propriedade indígena", situação que trouxe percalços acerca da disputa da posse da terra no Estado, conflitos que perduram até os dias atuais.

A partir dessa ideologia nacionalista, o governo Vargas empreendeu esforços para alcançar seus objetivos. Uma das medidas tomadas foi criar uma série de Colônias Agrícolas Nacionais, sendo que, na Região CentroOeste, foram instituídas a Colônia Agrícola de Goiás (CANG) e a Colônia Agrícola Nacional de Dourados (CAND), com intuito de ocupar os espaços denominados "vazios". Seguindo ainda a linha de ações intervencionistas, criou instituições para auxiliar neste processo, como é o caso do Conselho Nacional de Estatística e do Conselho Brasileiro de Geografia (que em 1938 tornaram-se o Instituto Brasileiro de Geografia e Estatística - IBGE), do Instituto Nacional de Imigração e Colonização (INIC), entre outros. Especificamente na região objeto de análise, destaca-se ainda a criação do Território Federal de Ponta Porã (MS), que, junto com o de Iguaçu (PR), foi instituído com a finalidade de nacionalizar a fronteira.

8 Para uma discussão adicional sobre "um ciclo de medidas fiscais" durante o período Imperial ver Queiroz (2017). 
Na década de 1930, após a crise do setor cafeeiro, o Estado iniciou o "Processo de Substituição de Importações", que, em linhas gerais, objetivava a substituição pela produção nacional de bens manufaturados até então importados. Não obstante, como a literatura já demonstrou, a industrialização desenvolvida neste período foi incompleta, em geral centrando-se na produção de bens de consumo ou também na chamada indústria leve.

Posteriormente, aprofundou-se o reconhecimento da necessidade de inserção do Brasil num processo de industrialização de base (pesada) capaz de romper com as amarras e características periféricas. É nesse cenário que são desenvolvidas as ações já citadas como a Marcha para o Oeste (criação das colônias), a criação do BNDES (1952) e da Petrobrás (1953), que podem ser entendidas como ações que buscavam preparar o país para novo processo de industrialização pesada (que avançasse na produção de bens de capital, por exemplo). Contudo, essa industrialização ficou restrita à Região Sudeste, prioritariamente no estado de São Paulo, onde estava concentrado o capital cafeeiro e seus derivados. Segundo Tavares $(2011,102)$, isso ocasionou um [...] um agravamento considerável das pressões inflacionárias e dos desequilíbrios regionais".

Entrelaçado à industrialização, iniciou-se o processo de urbanização do país, especialmente daqueles estados onde a indústria tinha se instalado, sendo que, neste processo, a Região Centro-Oeste passou a desempenhar um duplo papel, ora como fornecedor de matérias-primas e produtos de subsistência, ora como importador de produtos industrializados (especialmente aqueles produzidos pela indústria como insumos agrícolas, fertilizantes, entre outros).

Em síntese, admite-se que a tentativa de modernização da agricultura e de ocupação da fronteira Oeste é um processo complementar à concentração industrial e à crescente acumulação de capital da região sudeste. Nesse sentido, a região é incorporada de maneira periférica ao mercado nacional e a Marcha para o Oeste pode ser considerada um marco desse processo, que foi se intensificando durante os governos subsequentes.

Reforçamos o entendimento de que o Sudeste também exerceu um papel de "centro" no processo de desenvolvimento de MS. Embora tenha ocorrido uma "maior" ocupação populacional da região, bem como uma "maior" integração à economia nacional, as atividades desenvolvidas vinculavam-se aos ciclos econômicos do Sudeste e, portanto, a produção era destinada 
a atender os interesses daquele mercado consumidor. Mais do que isso, a produção a ser realizada em MS era essencialmente de bens não industrializados, em geral associados a bens alimentícios e/ou produtos de origem agropecuária a serem utilizados pela indústria nascente localizada em São Paulo.

Especificamente no caso do antigo sul de Mato Grosso, tem-se, em um primeiro momento, o desenvolvimento e especialização da atividade ligada à pecuária. A região, nesse período, pode ser considerada uma extensão econômica da Região Sudeste, em especial de São Paulo, uma vez que sua função era abastecer o mercado paulista. Ressalta-se que na década de 1960 o gado exportado para São Paulo era o gado magro.

Do ponto de vista político, cumpre ressaltar as alterações que ocorrem a partir da revolução constitucionalista. Com o golpe militar no Brasil, em 1930, Getúlio Vargas assumiu o poder, constituindo o denominado "Governo Provisório". Descontentes com as ações de Vargas, as oligarquias paulistas se uniram contra seu governo no ano de 1932, recebendo apoio de parte das oligarquias de Minas Gerais, Rio Grande do Sul e Mato Grosso.

Bittar (2009) mostra que a partir desse movimento houve alteração na lógica política até então existente em MT, ou seja, a partir de então, o SMT passou a ser influenciado mais por elementos políticos advindos dos grandes centros, em especial, São Paulo, do que por Cuiabá. Além disso, o regionalismo passou a predominar no palco da disputa política, acentuando a rivalidade entre o "norte" e "sul" de Mato Grosso. Desse modo, o ideal separatista foi se fortalecendo, o que possibilitou inclusive a consolidação da liderança de Campo Grande como centro político e econômico do SMT.

Assim, mesmo não sendo o elemento definitivo, é possível considerar que este segundo momento tem influência importante na separação política do Estado. Sua importância está relacionada, em primeiro lugar, à consolidação das bases econômicas da região. Mais especificamente, cumpre lembrar que, conforme defendido no documento de 1934, intitulado "A divisão de Mato Grosso: resposta ao General Rondon”, o STM já se sobressai economicamente na região. ${ }^{9}$ Posteriormente, com o desenrolar do movimento iniciado com a Marcha para o Oeste, é necessário ressaltar

9 Como exemplo, no documento consta que, em 1934, o centro de Mato Grosso detinha um rebanho de 500 mil rezes, enquanto que o do sul era possuidor de 3 milhões (sem contar Corumbá). Ou ainda, consta que mais de dois terços da receita gerada em MT era proveniente das exportações realizadas a partir do SMT. 
que a implantação das inovações tecnológicas e, portanto, o consequente desenvolvimento do campo, somente foi possível a partir das políticas de financiamento e de incentivos do Estado Nacional. ${ }^{10}$

Acontece que a política de financiamento adotada não abarcava todos os produtores. $\mathrm{Ou}$, em outras palavras, nem todas as regiões brasileiras receberam os incentivos estatais que favoreciam a agricultura agroindustrializada, mas somente aquelas que detinham as condições mais favoráveis ao desenvolvimento inerente à agricultura moderna. Na região Centro-Oeste, Teixeira (2009) aponta que Goiás e o antigo sul de Mato Grosso concentravam o uso de máquinas e insumos modernos, ou seja, eram as áreas com as condições mais favoráveis.

Somado a isso, em segundo lugar, é necessário observar que este processo (modernização do campo) foi levado adiante sem o rompimento com as elites locais, ou seja, manteve-se o Status Quo. As décadas de 1960-1970 foram marcadas pelo desenvolvimento capitalista na agricultura brasileira, quando se verificou a penetração do progresso tecnológico nas unidades agrícolas. Porém, conforme aponta Pires (2008), esse período não representa apenas o ingresso da tecnologia no campo, mas também demonstra "[...] o pacto político conservador urdido entre a burguesia nacional e os terratenentes no interior do Estado que determinou o rumo e o ritmo do desenvolvimento capitalista na sociedade nacional" (p. 16). Ou seja, trata-se da Modernização Conservadora, como já bem explorada na literatura.

Portanto, o atendimento aos interesses das elites agrárias do SMT, da elite industrial do Sudeste e dos interesses do Estado Nacional ${ }^{11}$ reforçou a causa divisionista. Esses interesses traduziram-se no modelo econômico que se desenvolve na região a partir da década de 1970, conforme relatado no terceiro momento.

Por fim, cumpre observar que no período compreendido entre 1970 e início de 1980 ficou bastante nítida a relação centro-periferia entre o SMT e São Paulo, bem como a sua dependência cultural em relação aos paulistas, pois a partir da modernização conservadora fica claro que à primeira área

${ }^{10}$ Segundo Pires $(2000,116)$ " [...] as linhas de crédito implantadas pelo governo estavam atreladas à compra de insumos modernos, ampliando a dependência do setor produtivo agrícola ao setor produtor de insumos", ou seja, por meio dos incentivos e subsídios, o Estado criava demandas aos produtos agroindustriais.

11 Interesses nacionais que incluem, entre outros, preocupações geopolíticas e também de apoio político ao regime ditatorial. 
caberia o fornecimento de alimentos e matérias-primas para o desenvolvimento industrial da Região Sudeste como um todo. ${ }^{12}$ Verificou-se, nesse período, que as políticas adotadas pelo Estado Nacional estimulavam a adoção de técnicas e inovações para o desenvolvimento de determinadas commodities agrícolas, a saber, soja e milho. Exemplo de incentivos são os financiamentos concedidos com reduzidas taxas de juros.

\subsection{Modelo Agroexportador}

E, por fim, o terceiro momento foi fruto das ações empreendidas ao final da década de 1970, quando se sobressai a ideia do "modelo agroexportador", com vistas a atender à demanda do mercado externo. Isto é, a economia brasileira volta-se novamente "para fora", tendo sua dinâmica determinada mais uma vez pelo cenário externo.

O fato é que as políticas desenvolvimentistas empreendidas desde a era Vargas resultaram no endividamento externo do país (crise do endividamento). A alternativa apontada para a falta de divisas foi a ampliação das exportações de commodities agrícolas e, dentro deste contexto, dadas as características e condições históricas, grande parte dessa função foi designada à região centro-oeste e ao Mato Grosso do Sul, em particular. ${ }^{13}$

Trindade et al. (2011) destaca que, durante o final da década de 1980 e início da década de 1990, o Brasil apresentou um superávit comercial considerável e crescente, situação que se repetiu a partir de 2001 e se estendeu nos anos seguintes. A pauta das exportações é basicamente composta de bens primários e o seu crescimento atende aos estímulos de desenvol-

12 Destaca-se, ainda, que ao contrário de países onde a revolução burguesa ocorreu por meio da ruptura com a estrutura política e econômica do antigo regime, retirando os proprietários rurais do centro do poder político, no Brasil, a burguesia nacional não deteve força suficiente para uma ruptura profunda com as antigas elites dominantes. O que se verificou foi um pacto político e econômico entre esses agentes (e que no MT uno predominou a elite agrária e, na Região Sudeste, a burguesia industrial). Em MT uno, essa aliança de interesses, embora apareça em contexto diferente, também estava presente. Valmir Corrêa (2006) exemplifica isso ao mostrar que o monopólio para exploração da erva-mate pela Companhia Mate Laranjeira (localizada no sul do estado) foi estabelecido com a conivência de políticos mato-grossenses e também do Governo Federal. No contexto da exploração da erva-mate, essa aliança fica mais evidente quando da associação dos irmãos Murtinho (que exerceram repetidas vezes cargos políticos na esfera estadual e federal) à Companhia Mate Laranjeira. Segundo Bittar $(2009,64)$, observava-se "utilização do poder público para fins particulares".

${ }^{13}$ Lamoso (2011) e Sangallie Lamoso (2014) mostram a estreita relação comercial atual existente entre o MS e a China. 
vimento das economias externas. ${ }^{14}$ A busca por essas divisas levou essas regiões a se especializarem cada vez mais nesta política agroexportadora.

Levando em consideração tais argumentos, adaptados em termos regionais, considera-se que o "sentido da colonização" pode ser um guia útil para a compreensão do processo de formação de Mato Grosso do Sul. A justificativa advém do entendimento de que, no Mato Grosso uno, em geral, mesmo com suas especificidades, a forma de ocupação foi uma reprodução do formato da ocupação do Brasil e, portanto, ocorreu com o propósito de exploração da produção para atender inicialmente ao mercado internacional (leia-se o mercado europeu) e, posteriormente, ao mercado nacional (região sudeste do Brasil). Em outras palavras, a acumulação seguiu a lógica de atendimento às demandas externas (internacionais e/ou regionais).

Apesar dessa inserção periférica da região que comporta o atual estado de MS, cumpre ressaltar o entendimento de que a simples relação de trocas comerciais não é condição suficiente para explicar o atraso econômico da região (em termos do processo de industrialização, especialmente). É, portanto, necessário estudar as características e especificidades locais que condicionam este processo. Este é o objetivo da próxima seção.

\section{Especificidades Locais e Inserção Periférica}

As transformações nacionais decorrem de ações de elementos externos (sejam voluntários ou involuntários) combinados a fatores internos/locais (inclusive políticos e sociais). No SMT, esses elementos internos tiveram importância significativa, isto é, reforçaram/contribuíram para a inserção periférica e dependente desse território. Neste caso, destacam-se quatro elementos estruturais principais: ${ }^{15}$ i) a distância em relação ao centro dinâmico; ii) a ausência de um mercado consumidor; iii) a insuficiência de mão de obra; e, por fim, iv) a ausência de acumulação de capital. Tais determi-

\footnotetext{
${ }^{14}$ Recentemente voltada para atender ao boom da economia chinesa.

${ }^{15}$ A existência por si só desses elementos não determinou a inserção periférica e dependente, uma vez que, como historicamente pode ser observado, guardada as concessões necessárias, eles podem ser "superáveis", tal como ocorreu na expansão para o oeste nos Estados Unidos. O que estamos argumentando é que esses elementos, somados a um complexo de condições, naquele contexto histórico e social específico, acabaram por moldar o processo de desenvolvimento em MS, tal como identificado ao longo deste estudo.
} 
nantes são corroborados em Borges $(2001,89)$ quando cita um relatório de Dr. Joaquim Ramos Ferreira (1887):

(...) Como produzir onde falta o consumidor, onde não existem vias de comunicação, e os mercados por sua grande distância tornam absurda toda a idéia de permute? Pois podem os productos agrícolas de Matto-Grosso ser remetidos para Buenos Ayres e Montevideo, para competir com os similares de outras procedencias, quando só o preço do frete quase que absorve o valor do produto?

Outra causa é a falta de capitaes. A província não possue um só estabelecimento bancário, e o capitalista mattogrossense só conhece um emprego para os seus capitaes - as apólices da dívida pública. ${ }^{16}$

O primeiro elemento interno apontado como um dos empecilhos para o desenvolvimento de MT uno é a distância, ${ }^{17}$ que, por si só, não pode ser considerada como único determinante do não desenvolvimento deste território, ainda que representasse um dos principais gargalos para a ocupação do oeste brasileiro. A distância em relação aos demais núcleos urbanos, especialmente aqueles que concentravam o núcleo político do país (Rio de Janeiro, em especial) implicava, por exemplo, limitada comunicação ou comunicação tardia. ${ }^{18}$ Ademais, a precariedade das estradas (quando existiam estradas!) associadas à distância, e, consequentemente, às dificuldade de transporte, obstruíam a possibilidade de uma integração de Mato Grosso com as demais regiões do Brasil (retomamos este ponto na próxima seção). Conforme qualifica Soares $(2013,42)$ :

${ }^{16}$ Relatório que o Exmo. Sr. Vice-Presidente Dr. José Joaquim Ramos Ferreira devia apresentar à As-

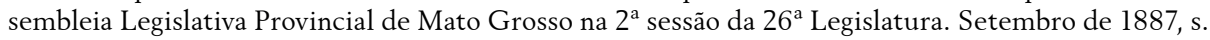
p. (Borges 2001, 89).

17 No que se refere à distância, Borges (2001) aponta que, dentro da historiografia de Mato Grosso, existe uma corrente tradicional que se utiliza da tese de isolamento para explicar a ausência de desenvolvimento da Província/Estado. Entretanto, a historiografia recente tem criticado essa tese, pois acredita que este isolamento não ocorreu em sua totalidade (Borges 2001, 22).

${ }^{18}$ Borges (2001) relata que a notícia da Proclamação da República (ocorrida em 1889) chegou a Cuiabá quase um mês após o episódio, o que nos remete a uma reflexão de quão deficiente era a infraestrutura neste período e, principalmente, anterior a ele. 
As dificuldades de transporte, a indefinição acerca da posse do território até a assinatura do Tratado de Madrid (1750) e a grande disponibilidade de terras próximas ao litoral para as produções de exportação inviabilizaram uma integração produtiva significativa do oeste ao restante do Brasil.

O segundo elemento listado é a ausência de um mercado consumidor, em grande parte porque a própria distância dificultava a formação de núcleos maiores de povoamento. Ao mesmo tempo, em parte devido a essa baixa densidade demográfica, havia a escassez de mão de obra (terceiro elemento), o que, por sua vez, dificultava a diversificação produtiva. A mão de obra era predominantemente escrava (principalmente durante o ciclo do ouro), e, mesmo após a abolição, nas principais atividades estabelecidas em MT uno o trabalho assalariado não era estabelecido de forma plena, vigorando o "endividamento" (servidão por dívidas) como regime de trabalho. Isso fica claro no ciclo da extração da borracha e da erva-mate, por exemplo.

O quarto elemento é a baixa acumulação de capital. Isso, em boa parte, é decorrência dos três elementos citados anteriormente, bem como por não haver na região (assim como em boa parte das demais regiões brasileiras) um núcleo de "desenvolvimento" comparado àquele desenvolvido pela economia cafeeira em São Paulo, por exemplo. Em outras palavras, a região não contava com nenhum produto que permitisse se conectar com os ciclos de expansão do comércio mundial (do próprio capitalismo), dificultando, portanto, a formação de uma acumulação de capital capaz de liderar o processo de desenvolvimento (ainda que em condição de dependência). Ademais, a acumulação que ocorreu (por meio da companhia Mate Laranjeira) era monopolizada e em grande parte respondia a interesses externos.

Além disso, é possível mostrar que, no processo de acumulação, o capital externo (nacional e internacional) foi ganhando espaço ao final do século XIX e início do século XX no antigo sul de Mato Grosso. Pires (2008) revela que mesmo no ciclo do ouro os mineradores tinham de pagar uma alta parcela de tributos à coroa lusitana, reduzindo assim sua renda. Salienta-se, também, que boa parte das mercadorias (alimentos e bens de consumo não duráveis) era proveniente de outras capitanias (principalmente São Paulo), o que resultava em preços elevados e, assim, na redução da capitalização 
dos agentes econômicos, o que impossibilitava a formação de um mercado consumidor sólido.

Borges (2001) identifica que existiam incipientes atividades voltadas ao mercado interno acontecendo paralelamente à mineração de ouro, embora elas fossem insuficientes para atender à demanda local. Com o declínio da atividade mineradora, restando apenas como alternativa a exportação de limitadas porções de couros e de poaia, reduziu-se a capacidade que a Capitania detinha para importar (situação que já era desfavorável pelos apontamentos anteriores). Surge a necessidade de maiores "estímulos" para produção interna, ou ainda, de um reordenamento das forças produtivas (Lenharo 1982).

Dessa forma, desenvolveu-se predominantemente na região a agricultura de subsistência e a pecuária extensiva (que foi se transformando na atividade preponderante). Foi dessa junção que historicamente se formou uma estrutura fundiária caracterizada pela média e grande propriedade rural, originando uma elite agrária que passou a concentrar o poder político. Em outras palavras, deve-se levar em consideração, também, para além dos determinantes estruturais do desenvolvimento dependente, os elementos de ordem político-institucional que se somaram aos primeiros na conformação do modelo de desenvolvimento da região. Bittar (2009) argumenta que, durante a Primeira República (1889-1930), dada a dispersão geográfica brasileira, o processo político foi caracterizado pelo surgimento de poderes locais. No caso de MT uno, esse período foi marcado pelas oligarquias e pela presença do denominado coronelismo, os quais defendiam interesses ligados à classe latifundiária.

O mercado consumidor ampliou-se ao final do século XIX na Província de Mato Grosso mediante incremento da demanda externa, uma vez que nesse período houve considerável abertura econômica propiciada pela navegação do rio Paraguai. Ao final do século, o mate e a borracha foram os responsáveis pela superação da "relativa estagnação produtiva de Mato Grosso" (Borges 2001, 47).

É reconhecido que a exploração da erva-mate contribuiu com a economia de MT uno (especialmente com o SMT). Não obstante, é importante considerar dois pontos: i) sua exploração ocorreu por um período considerável 
de forma monopolizada pela Companhia Mate Laranjeira; e ii) a maior parte do capital da empresa era de origem externa (leia-se argentino), consequentemente, ainda que algumas benfeitorias tivessem sido realizadas na região, o fato é que boa parte do capital gerado pela exploração dessa cultura não ficava nesse território, mas migrava para a Argentina. Além do mais, preponderava o regime de semi escravidão junto à mão de obra utilizada na companhia, o que dificultava a formação de um mercado consumidor interno.

Por fim, é indispensável incluir o papel do Estado Nacional no processo de formação econômica dessa região. Destaca-se que, se no início da constituição de MT uno o Estado Nacional parecia ausente ${ }^{19}$ ou com pouca atuação, aos poucos esse cenário foi se alterando, como, por exemplo, no período pós-guerra do Paraguai e, principalmente, a partir do estabelecimento do Governo Vargas, na década de 1930, momento em que o Estado passou a intervir diretamente na região via programas de desenvolvimento. Desse modo, a forma de atuação do Estado Nacional ("aparente ausência" ou "intervencionista") acarretou consequências tanto de ordem política quanto econômica e social no SMT.

A atuação do Estado, tanto no sul de Mato Grosso, bem como em várias regiões do Brasil, ocorreu de forma mais direta a partir do estabelecimento das políticas desenvolvimentistas, em especial a partir da implantação dos programas criados pelo governo (POLOCENTRO, PRODEGRAN, PRODEPAN, entre outros), disponibilizando para tal todo um aparato administrativo (criação de superintendências, como a Sudeco, centros de pesquisa, como a Embrapa e a Emater).

Além dos determinantes internos e externos, o antigo Mato Grosso-por ser uma região fronteiriça- se beneficiou de políticas de "financiamento" por parte do governo imperial, principalmente após o declínio da exploração do ouro. Queiroz (2011) aponta que o governo imperial concedeu consecutivas isenções tributárias, além de efetuar gastos militares de ordem expressiva na região. Outra forma direta de atuação do Estado ocorre quando da construção da Estrada de Ferro Noroeste do Brasil (NOB).

${ }^{19}$ A ausência referida não está relacionada literalmente ao descaso, mas muitas vezes atrelada às circunstâncias do período e da região. Um exemplo típico desse processo é citado por Bittar (2009) extraído de Carone (1978), que relata a forma como Generoso Ponce toma Cuiabá e depõe Totó Paes, em 1906, e, embora Rodrigues Alves seja contrário a Ponce, nada pôde fazer, uma vez que, quando o General Dantas Barreto chegou à Cuiabá, o novo governo já estava instalado, restando ao então presidente reconhecer o novo governo. 
Na próxima seção definem-se as particularidades "históricas", tidas como indispensáveis para o estudo da formação histórica e econômica de MS. Evidentemente, privilegiá-las não significa que não possam existir outras (que poderão ser estabelecidas em estudos posteriores).

\section{Aspectos Históricos da Formação de MS}

Como observado, uma vez que os bandeirantes passaram a se "aventurar" ao norte do antigo Mato Grosso, acabaram casualmente descobrindo as jazidas de ouro de aluvião (entre 1718-1719); o resultado dessa descoberta, conforme já apontado, despertou o interesse do governo português em dominar este território. Nesse contexto, os rios desempenharam um importante papel no antigo Mato Grosso. Ou seja, durante o ciclo do ouro, o trajeto realizado entre Cuiabá e São Paulo ocorreu em grande parte pelas expedições fluviais denominadas monções, que, de acordo com Queiroz $(2008,17)$, "constituíram uma corrente regular de comunicações e comércio". Faziam parte deste trajeto os rios pertencentes à América Portuguesa (Tietê, Paraná, Pardo, Coxim, Cuiabá, entre outros) e uma parte do rio Paraguai (Mapa 1).

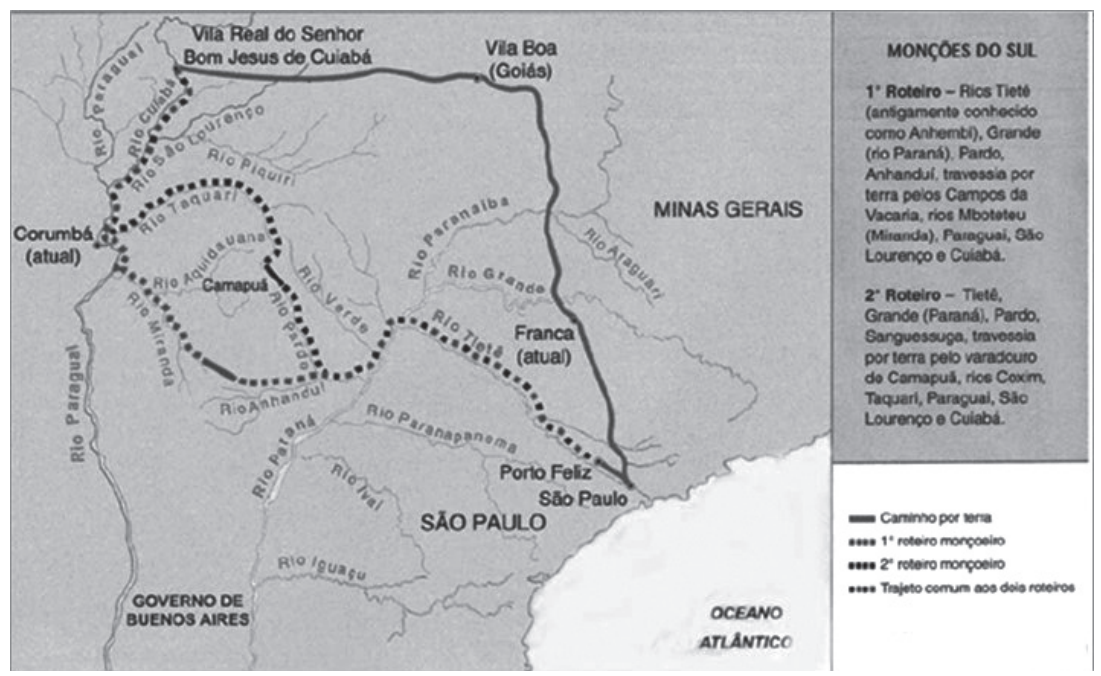

Mapa 1- Roteiros Monçoeiros (São Paulo - Cuiabá)

Fonte: Siqueira (2002 apud Diniz 2006) 
A navegação pelo rio Paraguai era apontada como melhor alternativa de comunicação entre o Mato Grosso e demais regiões, já que as condições de viagem eram melhores que aquelas efetuadas por vias terrestres, até então realizadas em lombo de mula, ou mesmo daquelas realizadas pelas vias fluviais interiores, que se caracterizavam por trechos encachoeirados. A navegação também beneficiaria as relações comerciais, seja pelo barateamento do custo das mercadorias devido à redução dos gastos com transporte (dado em grande parte ao considerável encurtamento do tempo de duração da viagem) ou pelo maior acesso ao mercado internacional. Nesse sentido, ela era considerada uma alternativa vital para o abastecimento, bem como para o escoamento de matérias-primas da região, além de facilitar o aparelhamento militar da fronteira. Ademais, o custo praticamente nulo contrastava com o grande volume de investimentos requeridos por outras alternativas de transporte, como a construção de uma estrada de ferro.

Entretanto, a rota pelo estuário da Prata permanecia bloqueada aos luso-brasileiros, sendo controlada pelos espanhóis "[...] até o médio curso do rio Paraguai, onde possuíam não apenas Assunção como também, mais ao norte, a vila de Concepción (1773) [...]” (Queiroz 2011, 110).

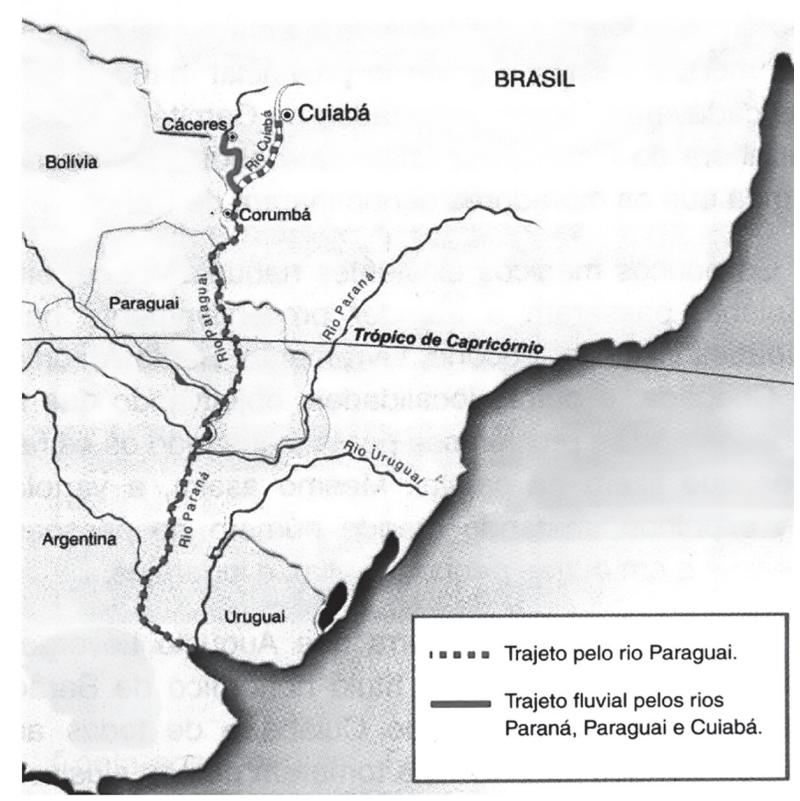

Mapa 2 -Trajeto fluvial na bacia do Prata (1870 a 1930)

Fonte: Silva (2002 apud Gomes, 2009, p. 13) 
Ao final da década de 1830, os dirigentes brasileiros, em especial os políticos de Mato Grosso, buscavam meios para que a livre navegação pelo rio Paraguai fosse concedida, uma vez que o empecilho para que a mesma não fosse realizada era de ordem política. A esperada liberação do trecho paraguaio para navegação ocorreu somente em 1856. Doratioto (2012) afirma que a liberação ocorreu após pressão política do Império brasileiro, que ameaçou entrar em guerra com o Paraguai caso a livre navegação não fosse concedida. Como o Paraguai não estava preparado para este conflito, acabou cedendo às pressões brasileiras. Apesar de ter assinado o tratado de livre navegação, em 1856, na prática, os dois países tiveram várias indisposições, o que levou a assinatura de uma convenção adicional no ano de 1858.

A abertura do rio Paraguai trouxe uma nova dinâmica para a Província de Mato Grosso. O governo imperial providenciou para que se instalasse uma empresa de navegação, mediante subvenção, cujo trajeto se daria entre Montevidéu e Cuiabá, ou seja, surgiu assim a Companhia de Navegação do Alto Paraguai, que passou a atuar ao final de 1859. Além disso, a cidade de Corumbá (até então denominada Albuquerque) começou a se destacar, pois sua localização favorecia o comércio, uma vez que a navegação até a referida cidade comportava inclusive embarcações oceânicas, situação oposta aos afluentes que chegavam à Cuiabá (onde não era possível o trânsito de embarcações de grande porte). Desse modo, devido às possibilidades de transformação da região em um centro comercial, bem como sua condição fronteiriça, Corumbá passou a receber investimentos "[...] para seu aparelhamento urbano e militar [...]” (Queiroz 2011, 119).

Esses investimentos favoreceram o povoado daquela área e possibilitaram a instalação de casas comerciais, pois surgia uma massa consumidora formada especialmente pela presença dos militares que se instalaram naquela localidade. Entretanto, esse princípio de dinamização do antigo sul de Mato Grosso foi interrompido com o fim da livre navegação e com a Guerra do Paraguai (em 1864/1865). O conflito implicou na destruição de vilarejos e na fuga de grande parte da já escassa população (em especial de Corumbá e Miranda).

Na opinião de Valmir Corrêa $(2006,51)$, entre as principais consequências, em território mato-grossense, da Guerra da Tríplice Aliança, tem-se a: "[...] internacionalização das águas do rio Paraguai até o porto de Corumbá, que se tornou no período subsequente o mais importante entreposto co- 
mercial de Mato Grosso". Ademais, nas palavras de Bittar (2009, p. 60): "[...] além de ter resolvido problemas de fronteira favoravelmente ao sul de Mato Grosso, suscitou dois processos que se tornariam determinantes para o recrudescimento do regionalismo sul-mato-grossense: a construção da ferrovia e a implantação da economia ervateira".

Com o fim da guerra, surge novamente a preocupação com a questão fronteiriça de Mato Grosso uno, pois ficou evidente a dependência brasileira, sobretudo desta Província, com relação à utilização do rio Paraguai para fins comerciais, especialmente para acesso ao mercado externo. Evidenciou-se, também, a fragilidade no que se refere ao domínio do território.

Estas questões foram parcialmente sanadas apenas no início do século XX, quando da construção da estrada de ferro ligando o antigo Mato Grosso à Região Sudeste do Brasil.

O Paraguai liberou novamente a livre navegação ainda em 1870 (Borges 2001). A partir de então, as relações comerciais do antigo Mato Grosso com o mercado mundial intensificaram-se, fazendo com que o polo comercial de Corumbá se tornasse cada vez mais importante. Queiroz (2008) argumenta que diante dessa nova oportunidade comercial, despontou-se a exploração e comercialização da erva-mate do sul do antigo Mato Grosso.

Corrêa Filho (1925) afirma que a expansão da indústria ervateira no antigo Mato Grosso ocorreu no contexto de demarcação das fronteiras entre Brasil e Paraguai, sendo que entre os integrantes desse trabalho fazia parte Tomás Laranjeira, que se tornou um dos grandes expoentes do denominado "ciclo ervateiro". Diante do potencial para exploração da erva-mate nativa encontrada em áreas do antigo sul de Mato Grosso, Laranjeira pleiteou a permissão para exploração econômica da erva-mate. Por meio do Decreto do governo imperial no 8.799 de 09/12/1882, foi concedida a permissão para que ele fizesse a colheita da erva-mate (Corrêa Filho 1925). Essa concessão foi ampliada (em termos da área concedida) e prorrogada várias vezes, o que resultou na formação de um monopólio em torno dessa atividade econômica por um período considerável de tempo. ${ }^{20}$

${ }^{20}$ Legalmente, o monopólio da Companhia Mate Laranjeira durou até o ano de 1915. Todavia, apesar da nova legislação vigente, dada a influência política que essa empresa possuía, a mesma permaneceu com forte atuação na exploração da erva-mate até o limiar da década de 1940. 
A atividade de exploração da erva-mate era permeada pelo interesse mútuo entre os dirigentes da companhia e a classe política de Mato Grosso.

Entre as características do "ciclo ervateiro" do antigo sul de Mato Grosso destaca-se a sua relação comercial voltada ao mercado externo, sendo que a Argentina era praticamente seu único mercado consumidor (Queiroz 2015). Apesar de já existir a exploração da erva-mate por pequenos produtores, foi a partir das ações empreendidas por Tomás Laranjeira que se iniciou o aproveitamento em maior escala.

Para exploração de suas concessões, em 1891, Laranjeira foi autorizado a criar a Companhia Mate Laranjeira, cujo principal acionista era o Banco Rio e Mato Grosso (BRMT), que detinha 97\% das ações. Entre 1902 e 1903, o Banco Rio e Mato Grosso foi liquidado, momento em que os bens e concessões da Companhia Mate Laranjeira foram assumidos pela empresa Laranjeira, Mendes \& Cia, originária na Argentina (Queiroz 2015). Segundo Bittar (2009), a mudança na companhia a tornava mais argentina do que brasileira. Nesta situação, ficou bastante evidente a estreita relação comercial com a Argentina, que na realidade já existia quando Laranjeira enviava a erva-mate cancheada a Buenos Aires (à empresa Francisco Mendes \& Companhia), que ficava responsável pela conclusão do beneficiamento e posterior distribuição do produto ao mercado consumidor final.

Embora em termos nacionais a erva-mate produzida no MS não tenha participação significativa, uma vez que os ervais do Paraná e do Rio Grande do Sul exerciam este papel, a produção foi de grande importância tanto em termos econômicos quanto políticos para o desenvolvimento do território sul-mato-grossense (Pavão 2005), situação que pode ser ratificada na atuação da Companhia Mate Laranjeira. Nas palavras de Bittar (2009, 64): "por causa do seu poderio econômico, a Companhia começou a pretender o controle sobre o poder político de Mato Grosso".

Para Queiroz (2008), a Companhia Mate Laranjeira inibiu a formação de núcleos populacionais na região do antigo sul de Mato Grosso, especialmente quando da chegada dos rio-grandenses-do-sul ao final do século XIX, momento que se intensifica a disputa pela posse da terra.

Inicialmente desenvolvida com fins de subsistência, por sua vez a pecuária modifica-se a partir da primeira metade do século XIX, com o início da ocupação não indígena de forma efetiva no SMT, por meio da migração de 
mineiros, paulistas e cuiabanos, os quais passaram a desenvolver atividades duradouras naquele lugar, especialmente aquelas relacionadas à criação do gado bovino. A partir desse momento, instaura-se o início de uma integração nacional da Província Mato-Grossense, por meio das invernadas mineiras. Entretanto, a Guerra do Paraguai suspendeu o desenvolvimento dessa atividade, em especial no território pantaneiro, onde houve grande destruição das cidades que formavam aquela região.

Ao final do século XIX e início do século XX, as atividades ligadas à pecuária começaram a se destacar, como no caso da exportação de couro, da produção do charque e novamente da exportação do gado em pé para a Região Sudeste. Nesse caso, o vínculo maior era com São Paulo. Ao longo dos anos, por meio do desenvolvimento dessa atividade, foram se formando grandes latifúndios no território do SMT tanto por criadores locais quanto estrangeiros. Além disso, as técnicas de produção foram se aperfeiçoando e o antigo sul de Mato Grosso acabou por deter, a partir de então, um dos maiores rebanhos do país.

A construção da estrada de ferro altera o estreito relacionamento do antigo Mato Grosso com o comércio internacional, já que ela passa a ligar o antigo sul de Mato Grosso ao Sudeste, implicando melhores conexões com o mercado nacional, em especial com São Paulo. De acordo com Queiroz (2011), o principal objetivo da construção da ferrovia Noroeste do Brasil (NOB) tinha, na realidade, a intenção político-estratégica em Mato Grosso, pois, como o SMT tratava-se de uma região fronteiriça, mesmo que houvesse relações comerciais (gado bovino) entre Mato Grosso e São Paulo, estas não seriam o suficiente para tamanho investimento, principalmente por parte de Mato Grosso.

Em outras palavras, tratava-se de uma ação de ordem política e estratégica que se traduziu em termos econômicos e, assim, culminou no enfraquecimento e na independência da utilização do rio Paraguai pelo comércio brasileiro, além de ter estimulado as atividades ligadas ao charque.

Destaca-se que a construção da ferrovia iniciou-se em 1905 com o traçado Bauru-Cuiabá. Entretanto, dois anos depois, esse traçado foi alterado para Bauru-Corumbá. Uma das principais consequências dessa alteração foi o fato de Campo Grande tornar-se o principal polo comercial do estado de Mato Grosso. Mais do que isso, além de principal centro econômico do estado, Campo Grande passou a ser o centro político de SMT. Como 
observado, ali se desenvolveram as principais articulações, principalmente no início da década 1930, que culminariam no surgimento do movimento divisionista em Mato Grosso. ${ }^{21}$

Em relação ao povoamento decorrente da NOB em território mato-grossense, os estudos mostram que o efeito propulsor de povoamento não teve a mesma magnitude do trecho paulista, embora ela tenha ocorrido em torno de Campo Grande (Bittar 2009). Essa nova dinâmica propiciou que Campo Grande se tornasse um polo de destaque não somente no sul do antigo Mato Grosso, mas em todo o estado, o que, por sua vez, acirrou e/ ou despertou a rivalidade entre as elites de Cuiabá e Campo Grande.

A constituição dos Territórios Federais, bem como das Colônias Agrícolas Nacionais, tinha como finalidade assegurar a soberania brasileira sobre suas fronteiras. No caso do Território Federal de Ponta Porã, o objetivo era também enfraquecer a atuação da Companhia Mate Laranjeira (a qual era acusada de estar muito mais aliada ao capital estrangeiro do que ao nacional) (Jesus 2004). Além disso, a Companhia foi considerada pelo Estado Novo como antagonista ao processo de colonização e nacionalização da fronteira daquela região (Guillen 1999 apud Jesus 2004).

Em resumo, esses breves apontamentos mostram que a compreensão do processo de desenvolvimento sul-mato-grossense passa necessariamente pela análise de uma série de acontecimentos históricos, conflitos políticos e políticas de desenvolvimento. Evidentemente, uma análise com essa abrangência é de difícil execução e, portanto, há de se elencar (ainda que com algum grau de arbitrariedade) quais são os aspectos mais importantes. Nesse caso, identifica-se como indispensáveis na análise da formação histórica e econômica de MS uma análise integrada que leve em consideração: i) as Bandeiras; ii) o ciclo da Mineração; iii) a Guerra do Paraguai; iv) a exploração da erva-mate; v) a pecuária; vi) a construção da ferrovia; vii) a Marcha para o Oeste; e, viii) os planos e programas governamentais.

${ }^{21}$ É possível que essa mudança tenha acirrado o descompasso do desenvolvimento entre as duas regiões, com vantagens para o STM em contraposição a um atraso maior da região norte de MT. Não obstante, essa é uma questão a ser explorada ainda pela literatura. 


\section{Considerações Finais}

Historicamente, as primeiras incursões pelos territórios que hoje formam o Centro-Oeste brasileiro foram realizadas pelos bandeirantes com o objetivo de explorar os recursos dessa região, sejam eles humanos (escravização de mão de obra indígena) ou naturais (metais preciosos). Desse modo, assim como no cenário nacional, não havia a intenção de empreender qualquer atividade que tivesse a finalidade de desenvolver economicamente esta localidade.

Nesse período, o antigo sul de Mato Grosso, hoje Mato Grosso do Sul, exerceu papel coadjuvante à região central ${ }^{22}$ do estado, uma vez que em Cuiabá localizavam-se as jazidas de ouro, implicando, assim, a esta última maior relevância econômica naquele momento. Contudo, apesar do papel secundário do SMT no ciclo da mineração, a região se beneficiou indiretamente dessa atividade, dado que a partir de então a Coroa Portuguesa passou a realizar contínuos atos de posse com intuito de dominar a região mato-grossense.

Findado o ciclo do ouro no território de Mato Grosso (MT), somente por volta da década de 1830 é que o antigo sul de Mato Grosso passou a contar com uma ocupação efetiva, bem como com o desenvolvimento de atividades produtivas de longa duração, sobretudo, em torno do gado bovino. Ainda ao final do século XIX, outra atividade muito relevante nesta área se estabeleceu, isto é, a exploração da erva-mate. Ambas as atividades econômicas (gado bovino e exploração da erva-mate) tiveram em comum seu caráter de exploração extensiva e, entre as especificidades, destaca-se que, enquanto a primeira esteve voltada ao mercado nacional, o oposto ocorre com a atividade ervateira. Salienta-se, ainda, que no início do século XX atividades derivadas do gado bovino como as charqueadas também passam a ser desenvolvidas.

Foi por volta da segunda metade do século XX que o SMT ganhou importância econômica, quando, em termos nacionais, ocorre um reordenamento da produção, ou seja, inicia-se o processo de industrialização "pesada" no Brasil, concentrada na Região Sudeste, especialmente em São Paulo. Nesse período, por questões históricas (relacionadas a formação de capital, o

${ }^{22}$ De acordo com Queiroz (1997, p. 113): "Centro é como se costumava designar, na época, a região mato-grossense polarizada por Cuiabá (diferenciando-a do extremo norte, ainda virgem da presença branca)". 
nascimento de uma classe industrial e mesmo à posição geográfica) e por questões políticas e econômicas (jogo de interesses), a referida região acaba por dinamizar o processo de crescimento da economia brasileira, que passa a incorporar as demais regiões do território nacional, especialmente o Centro-Oeste.

\begin{abstract}
A questão é que, voluntária ou involuntariamente, coordenada ou não por interesses externos (esse não é o ponto!), a incorporação de MS ocorreu em termos periféricos, sendo a ele incumbido o papel de ser um dos "celeiros" do Brasil.
\end{abstract}

\title{
Referências
}

Abreu, Silvana de. 2003. "Ocupação, racionalização e consolidação do Centro-Oeste brasileiro: o espaço mato-grossense e a integração nacional”. In: Marin, J. R.; Vasconcelos, C. A. de. História, Região e Identidades. Campo Grande: UFMS, 263-290.

Bittar, Marisa. 2009. Mato Grosso do Sul a construção de um estado: regionalismo e divisionismo no sul de Mato Grosso. Campo Grande: Ed. UFMS, 2009.

Borges, Fernando Tadeu Miranda. 2001. Do extrativismo à pecuária: algumas observações sobre a história econômica de Mato Grosso (1870 a 1930). 2.ed. São Paulo: Scortecci, 2001.

Candido, Antônio. 1967.O significado de 'Raízes do Brasil. Prefácio, ed. 1967. In: HOLANDA, S. B. Raízes do Brasil. 26a . ed. 19a . reimpressão. São Paulo:Compania das Letras, 1995 [2004].

Corrêa Filho, Virgílio. 1925. À sombra dos hervaesmattogrossenses. São Paulo: S. Paulo, 1925.

Corrêa, Lúcia Salsa. 1999. História e fronteira: o Sul de Mato Grosso, 1870-1920. Campo Grande: UCDB, 1999. Corrêa, Valmir Batista. 2006.Coronéis e bandidos em Mato Grosso: 1889-1943. 2. ed. Campo Grande: Ed. UFMS, 2006.

Diniz, Bernardo Palhares Campolina. 2006. O Grande Cerrado do Brasil Central: geopolítica e economia. 231

f. Tese (Doutorado em Geografia Humana) - Universidade de São Paulo, São Paulo - SP, 2006.

Doratioto, Francisco. 2012. Relações Brasil-Paraguai: afastamento, tensões e reaproximação (1889-1954). Brasília-DF: FUNAG, 2012.

Esselin, Paulo Marcos. 2011. A pecuária bovina no processo de ocupação e desenvolvimento econômico do pantanal sul-mato-grossense (1830-1910). Dourados: Editora da UFGD, 2011.

Faria, Sheila de Castro.2008.A colonia é mais embaixo. A consagrada tese do Pacto Colonial de Caio Prado Júnior merece revisão. A sociedade brasileira era muito mais complexa do que se supunha. Disponível em: $<$ http:// www.revistadehistoria.com.br/secao/educacao/a-colonia-e-mais-embaixo>. Acesso em: 09 de nov. de 2015.

Furtado, Celso. 2005. Formação Econômica do Brasil. 32. ed. São Paulo: Companhia Editora Nacional, 2005. Fragoso, João Luís Ribeiro. 1992. "Homens de grossa aventura: acumulação e hierarquia na praça mercantil do Rio de Janeiro (1790-1830)”. Rio de Janeiro: Arquivo Nacional, 1992.

Fragoso, João Luís Ribeiro; Florentino, Manolo. 1993. “O arcaísmo como projeto. Mercado Atlântico, sociedade agrária e elite mercantil em uma economia colonial tardia c. 1790-c.1840”. Rio de Janeiro: Diadorim, 1993. 
Garcia, Domingos Savio da Cunha. 2001. "Mato Grosso (1850-1889): uma província na fronteira do império". Dissertação de mestrado, Universidade Estadual de Campinas. Instituto de Economia. Campinas, SP:[s.n.].

Gomes, Cristiane Thais do Amaral Cerzósimo. 2009. Fronteiras de imigração no caminho das águas do Prata: italianos em Mato Grosso - 1856 a 1914. 2009. 220 f. Tese (Doutorado em História Social) - Pontifícia Universidade Católica de São Paulo, São Paulo - SP, 2009.

Guimarães Neto, Leonardo. 1997. "Trajetória econômica de uma região periférica". Estudos Avançados1(29): 37-54, São Paulo, Apr. 1997.

Holanda, Sérgio Buarque de. 1995. Raizes do Brasil. 26. ed. São Paulo: Companhia das Letras, 1995.

Jesus, Laércio Cardoso de. 2004.Erva-Mate: o outro lado - A presença dos produtores independentes no antigo Sul de Mato Grosso 1870-1970. 2004. 191 f. Dissertação (Mestrado em História) - Universidade Federal de Mato Grosso do Sul, Dourados - MS, 2004.

Lamoso, Lisandra Pereira. 2011. "Dinâmicas Produtivas da Economia de Exportação do Mato Grosso do Sul Brasil”. Revista Mercator10(21): 33-47, Ceará, jan./abr. 2011.

Lenharo, Alcir. 1982. Crise e mudança na frente oeste de colonização: o comérciocolonial de Mato Grosso no contexto da mineração. Cuiabá: UFMT, 1982.

Martins, José de Souza. 1996. "O tempo da fronteira: retorno à controvérsia sobre o tempo histórico da frente de expansão e da frente pioneira”. Tempo Social, Revista de Sociologia da USP 8(1): 25-70, São Paulo, 1996.

Naglis, Suzana Gonçalves Batista. 2013. "A difícil conquista da terra para viver: as experiências dos colonos da Colônia Agrícola Nacional de Dourados”. In: Marin, J. O. B.; Neves, D. P. (org.) Campesinato e Marcha para Oeste. Santa Maria: Ed. Da UFSM, 2013.

Pavão, Eugênio da Silva. 2005. Formação, estrutura e dinâmica da economia do Mato Grosso do Sul no contexto das transformações da economia brasileira. 250 f. Dissertação (Mestrado em Economia Industrial) - Universidade Federal de Santa Catarina, Florianópolis - SC, 2005.

Pires, Mauro Oliveira. 2008. "Programas Agrícolas na ocupação do Cerrado". Sociedade e Cultura, Goiânia-GO, v. 3, n. 1 e 2, p. 111-131, jan/dez. 2000.Pires, Murilo José de Souza. As implicações do processo de modernização conservadora na estrutura e nas atividades agropecuárias da região centro-sul de Goiás.146f. Tese (Doutorado em Desenvolvimento Econômico) - Universidade Estadual de Campinas, Campinas - SP, 2008. Prado Jr., Caio. 2011. Formação do Brasil Contemporâneo: Colônia. São Paulo: Companhia das Letras, 2011.

Queiroz, Eduardo Pessoa de. 2007. A formação Histórica da região do Distrito Federal e entorno: dos Municípios-Gênese à presente configuração territorial. 135 f. Dissertação (Mestrado em Geografia) - Universidade de Brasília, Brasília - DF, 2007.

Queiroz, Paulo Roberto Cimó. 2011. "Caminhos e fronteiras: vias de transporte no extremo oeste do Brasil". In: Goulart Filho, A.; Queiroz, P. R. C. (orgs.) Transportes e Formação Regional: contribuições à história dos transportes no Brasil. Dourados: Editora da UFGD, 2011.

Queiroz, Paulo Roberto Cimó. 2015. “A Companhia Mate Laranjeira, 1891-1902: contribuição à história da empresa concessionária dos ervais do antigo sul de Mato Grosso". Territórios e Fronteiras8(1): 204-228, Cuiabá - MT, jan./jun. 2015.

Queiroz, Paulo Roberto Cimó. 2008. "Articulações econômicas de comunicação do antigo sul de Mato Grosso (séculos XIX e XX)”. In: Lamoso, L. P. (org.). Transportes e Políticas Públicas em Mato Grosso do Sul. Dourados: Editora da UFGD, v. 1, 2008.

Queiroz, Paulo Roberto Cimó. 1997.As curvas do trem e os meandros do poder: o nascimento da Estrada de Ferro Noroeste do Brasil (1904-1908). Campo Grande: UFMS, v.1, 1997.

Queiroz, Paulo Roberto Cimó. 2009. "O desafio do espaço platino às tendências de integração do antigo sul de Mato Grosso ao mercado nacional brasileiro: um hiato em dois tempos". Revista eletrônica História em reflexão 3(6), jul./dez. 2009. 
Queiroz, Paulo Roberto Cimó. 2017. “O livre comércio entre Mato Grosso e o Paraguai (1872-1898)”. In: XII Congresso Brasileiro de História Econômica e $13^{\text {a }}$ Conferência Internacional de História de Empresas, 2017, Niterói. Anais. Niterói: UFF/ABPHE, p. 1-35, 2017.

Sangalli, Larissa; Lamoso, Lisandra Pereira. 2014. O papel da China no comércio exterior da região Centro Oeste. In: ENEPEX ( $8^{\circ}$ ENEPE UFGD - 5 EPEX UEMS), Dourados, 2014. Disponível em:<http://eventos. ufgd.edu.br/enepex/anais/arquivos/307.pdf>. Acesso em: 17 de mai. de 2016.

Skocpol; Theda; Somers; Margaret. 1980. "The use of comparative history in macro-social inquiry". Comparative studies in Society and History, 22 (April), p. 174-197, 1980.

Soares, Herick Vazquez. 2013. A incorporação subordinada do Centro-Oeste ao capitalismo brasileiro: uma interpretação histórica. 210 f. Dissertação (Mestrado em História Econômica) - Universidade de São Paulo, São Paulo - SP, 2013.

Targa, L. R. P. 1991. Comentário sobre a utilização do método comparativo em análise regional. Ensaios FEE 12(1): 265-271, Porto Alegre, 1991.

Tavares, Maria da Conceição. 2011.O Processo de substituição de importações como modelo de desenvolvimento na América Latina/ o caso do Brasil. In: Corrêa, V. P.; Simioni, M. (orgs.). Desenvolvimento e igualdade. Rio de Janeiro: IPEA, 2011.

Teixeira, Jodenir Calixto. 2009. A inserção do Estado de Mato Grosso do Sul na modernização da agricultura brasileira. IV simpósio Internacional de Geografia Agrária; V Simpósio nacional de Geografia Agrária. Tema: A questão (da reforma) agrária na América Latina: Balanço e perspectivas, Niterói-RJ, 2009.

Trindade, José Raimundo Barreto; Seis dedos, Paul Cooney; Oliveira, Wesley de. 2011. "O aumento da participação das commodities brasileiras no mercado mundial: um novo processo de especialização primária?” In: V Encuentro Internacional de Economia Politica y Derechos Humanos, Buenos Aires. Anais do V Encuentro Internacional de Economia Politica y Derechos Humanos. Buenos Aieres: Editora da Universidad Popular Madres de Plaza de Mayo, 2011. 